\title{
AVENTURAS E DESVENTURAS DA ESCRITA. A PROPÓSITO DA INTERPRETAÇÃO DO NASCIMENTO DA ESCRITA NA MESOPOTÂMIA
}

ADVENTURES AND MISADVENTURES OF THE WRITING. ON THE INTERPRETATION OF THE BIRTH OF WRITING IN MESOPOTAMIA

Luc Bachelot

Como citar este artigo:

BACHELOT, Luc. Aventuras e desventuras da escrita. A propósito da interpretação do nascimento da escrita na Mesopotâmia. Cadernos do Lepaarq, v. XVII, n.33, p. 223-250, Jan-Jun. 2020. 


\title{
Aventuras e desventuras da escrita. A propósito da interpretação do nascimento da escrita na Mesopotâmia ${ }^{a}$
}

\author{
Luc Bachelot ${ }^{\mathrm{b}}$ \\ Tradução: Katia Maria Paim Pozzer. Revisão: Letticia B. R. Leite
}

Resumo: A aparição da escrita, pela primeira vez no mundo, na Mesopotâmia no final do quarto milênio antes de Cristo, foi e continua sendo percebida como uma verdadeira revolução, como a manifestação de um salto qualitativo da civilização tão espetacular quanto imprevisível. Esta é a nossa percepção ocidental, repetida ao longo dos séculos desde a Antiguidade grega, mas que não é universal. O Extremo Oriente tem uma concepção de escrita bem diferente. $\mathrm{O}$ exame atento dos fatos, assim como a abundância literária que suscitaram, incita a nos perguntarmos se a verdadeira aventura da escrita não foi na verdade uma desventura, que constitui essa historiografia agora milenar que não cessou de gerar uma sequência quase ininterrupta de estudos, discursos, mitos e histórias visando a descrever a sua origem. Vamos tentar tomar emprestadas questões que permitem uma saída desta desventura. Trata-se de questões que fazem parte dos trabalhos de Leroi-Gourhan, Derrida e A.-M. Christin, assim como dos avanços recentes da neurofisiologia, notadamente aqueles realizados por G. Rizzolatti. A escrita, assim como a palavra, é uma manifestação da atividade simbólica sem que a primeira esteja necessariamente submetida à segunda. A relação entre uma e outra não é vertical, mas horizontal. A escrita aparece então quando um campo de noções está suficientemente elaborado para poder ser expresso por um outro meio que não aquele da língua.

\begin{abstract}
For the first time in the world, the appearance of writing in Mesopotamia at the end of the fourth millennium $\mathrm{BC}$ was and continues to be perceived as a true revolution, as the manifestation of a qualitative leap of civilization, so spectacular and unpredictable. This is our Western perception, repeated over the centuries since the ancient Greeks, although it is not universal. There is a completely different perception of the writing for the Far East. The careful examination of the facts, along with the emerging abundant scholarship, raisesthe question whether the true adventure of writing wasin fact a mishap, which constitutes the now millenarian historiography that has not ceased to generate an almost uninterrupted sequence of studies, discourses, myths and histories in order to describe its origin. We will try to borrow questions that allow us to get out of this misadventure. Questions that form part of the work of Leroi-Gourhan, Derrida and A.M. Christin, as well as recent advances in neurophysiology, notably those by G. Rizzolatti. Writing, as speech, is a manifestation of symbolic activity, without the former necessarily being subjected to the second. The relationship of one to the other is not vertical but horizontal. The writing then appears when a notional field is sufficiently developed to be expressed by means other than that of language.
\end{abstract}

Keywords:

Writing, Mesopotamia, Language, Cuneiform, Sumerian,

Akkadian.

\section{Palavras Chave:}

Escrita, Mesopotâmia, Língua, Cuneiforme, Sumério, Acadiano. 


\section{Epígrafes}

1. "É surpreendente, quando se pensa nisso, constatar que o mito da origem verbal da escrita possa ter uma vida tão longa. Essa hipótese, entretanto, deveria parecer absurda para os linguistas há muito tempo" (CHRISTIN, 1995, p.11).

2. "Gostaríamos de sugerir que a assim chamada derivação da escrita, ainda que seja tão real e massiva, só seria possível se a linguagem original sempre tivesse sido ela mesma escrita (...)" (DERRIDA, 1967, p. 82).

3. "Mas, no entanto, se houvesse precisamente apenas a escrita do espaçamento e do mais material, do mais visível? Se acaso a experiência fenomenológica do vazio tivesse sido mais determinante na invenção do ideograma e em sua mutação em fonograma do que aquela da figura ou do signo?" (CHRISTIN, 1995, p.17).

4. “(...) sabemos que o espaço toma forma a partir dos objetos e da multiplicidade de atos coordenados que nos permitem alcançá-los. E como os objetos em si são apenas hipóteses de ação (...)" (RIZZOLATTI \& SINIGAGLIA, 2008, p. 88).

\section{INTRODUÇÃO ${ }^{1}$}

O termo "aventuras", no plural, tal como ele aparece no título deste artigo, evoca ao mesmo tempo uma multiplicidade de episódios ou realizações e seu caráter inesperado,

\footnotetext{
${ }^{1}$ Nota de apresentação à tradução do artigo de Luc Bachelot, por Katia M. P. Pozzer: Luc Bachelot é um arqueólogo com vasta experiência de campo, tendo participado, ao longo de mais de 25 anos, de escavações arqueológicas nas regiões conhecidas como Oriente Próximo e Levante, em países como o Iraque, a Síria, entre outros. Bachelot é um especialista do mundo cuneiforme e, como poucos, vale-se da transdisciplinaridade em seus estudos, conferindo uma grande riqueza aos seus escritos. Ele é um pesquisador conectado com seu tempo, curioso, leitor voraz, um erudito. E é assim que ele trata do tema da invenção da escrita cuneiforme neste artigo, que tive a honra de traduzir para a língua portuguesa. A presente publicação trata-se de uma versão revisada e atualizada pelo autor, em meados de 2019 , do texto publicado em 2017, no idioma francês, aqui nos Cadernos do LEPAARQ (14, 28, p. 128-155). Bachelot aborda, de forma eminentemente crítica, as tradições historiográficas acerca da invenção/surgimento da escrita na antiga Mesopotâmia. Recupera as reflexões da linguística, da fenomenologia e da semiótica sobre os estudos do funcionamento e da dinâmica da linguagem humana e as incorpora nos questionamentos sobre o desenvolvimento da escrita cuneiforme, mas também da língua acádica. Sem nenhuma dúvida, este artigo é leitura obrigatória para professores e estudantes das áreas de História, Letras, Linguística, Arqueologia, Comunicação, entre outras. E mais. Ele deve ser lido antes de qualquer outro, pois traz resultados de pesquisas recentes no âmbito da neurobiologia e suas contribuições para a arqueologia. É um artigo que questiona duramente ideias pré-estabelecidas e concepções hegemônicas sobre a primazia da escrita em relação à linguagem e que nos faz refletir sobre a boa prática científica e a relevância da dúvida.
} 
surpreendente. No que diz respeito à escrita, a diversidade dos contextos de seu surgimento, como a de suas manifestações, legitima amplamente essa designação. Mas além do número e da variedade dos sistemas de escrita conhecidos até agora, e tendo em vista o interesse fascinado das sociedades ocidentais pelos espetaculares avanços culturais que lhes são atribuídos (transmissão de conhecimentos, aceleração do progresso, dos conhecimentos, administração de grupos humanos, gestão econômica, etc.), o aparecimento da escrita, pela primeira vez no mundo, na Mesopotâmia, no final do quarto milênio a.C., foi e continua sendo percebido como uma verdadeira revolução. $O$ que não deixou de ser entendido como um salto qualitativo da civilização, tanto mais espetacular quanto imprevisível. Tal é a nossa percepção ocidental, repetida e reforçada ao longo dos séculos, desde a antiguidade grega, mas que, contudo, não é universal. O Extremo Oriente, por exemplo, tem uma concepção completamente diferente de escrita (CHRISTIN, 2001).

O exame cuidadoso dos fatos, assim como a abundante literatura que eles suscitaram, nos convidam a perguntar se a verdadeira aventura da escrita não foi, de fato, a desventura que constitui essa historiografia, agora milenar, que a assumiu e que até o momento não cessou de produzir uma sequência quase que ininterrupta de estudos, análises, discursos ou narrativas, mitos e histórias para descrever sua origem. Objetivo duplamente problemático: em si, -retornaremos a este ponto -, e em sua orientação em direção a um objeto que não pode ser descoberto, mas sim a um pressuposto que ela busca legitimar. Pressuposição segundo a qual a escrita seria essencialmente um produto derivado da língua.

Após relembrar as linhas de força que estruturam essa abundante literatura, tentaremos empregar estratagemas que, apesar de tudo, permitem uma saída dessa desventura. Subterfúgios representados pelos trabalhos de Leroi-Gourhan, Derrida e A.-M. Christin, bem como pelos recentes avanços da neurofisiologia, sobretudo aqueles apresentados por G. Rizzolatti.

Mas, de início, é imperativo que façamos uma nota sobre as definições mais comuns de escrita e os muitos estudos especializados nos quais elas se apoiam.

\section{I- Escrita: definições atuais...}

"A escrita é um sistema de representação gráfica de uma língua."

Definição dada pelo Trésor de la Langue Fraçaise (TLF), emblemática de uma concepção da escrita maciçamente difundida e que retoma aquela que já tinha curso no início do século XIX: "Por enquanto, atenho-me à ideia fundamental. Aquela da escrita propriamente dita, é de copiar os sons; já a da escrita hieroglífica, é de representar as ideias" (DESTUTT DE TRACY, 1803, p. 282) ${ }^{2}$.

Essa formulação evoca uma escrita que se poderia dizer verdadeira, "a escrita propriamente dita", que deveria "copiar os sons" e uma escrita hieroglífica, que supostamente representa as ideias e que, ao contrário, não poderia ser considerada como sendo realmente

${ }^{2}$ Citado por TLF. Disponível em: http://www.cnrtl.fr/definition/\%C3\%A9criture. 
uma escrita. Essa representação das "ideias" pelos signos não é outra coisa senão o que hoje é chamado de sistema ideográfico. Essa oposição, que está longe de ser evidente, teve, no entanto, uma impressionante longevidade, pois já era o que o idealismo de Platão ${ }^{3}$ estabelecera em primeiro lugar. Para Platão, a única escrita válida era a da verdade inscrita na alma; a outra, condenável, aquela que os homens aprenderam com o deus egípcio Theuth, seria apenas uma cópia enganosa.

Haveria assim, o discurso "(...) que transmite um saber, [que] se escreve na alma do homem que aprende, daquele que sabe (...)" e "o discurso escrito [que] é uma espécie de imagem" (PLATÃO. Fedra 276d-276e) ${ }^{4}$.

Para Destutt, há uma escrita que, como a de Platão, é considerada verdadeira, apenas na medida em que é capaz de "copiar os sons". Em ambos os casos, estabelece-se uma distinção entre dois tipos de escrita, uma carregada de verdade, a outra desvalorizada. É claro que o idealismo de Platão baseado no declínio (termo a partir do qual se escuta bem o "declínio") do mundo, indo da esfera das Ideias para a da matéria, poderia facilmente acomodar uma teoria da escrita, considerada secundária com relação à língua - esta última estando sempre mais próxima do mundo das Ideias. Ainda mais porque a escrita grega, assim como todos os sistemas alfabéticos, pareciam responder bem ao desejo de representar o discurso falado que necessariamente the precederia.

No século XIX, o desenvolvimento de pesquisas arqueológicas no Oriente Próximo trouxe muitos dados novos. Em poucas décadas, conseguimos entender como a escrita cuneiforme funcionava e como ela era usada para transcrever as muitas e diversas línguas que prevaleciam no Oriente Médio. O persa antigo, o acádico (com os componentes assírio e babilônico), o sumério etc., foram sucessivamente decifrados. Em 1801, são as observações do filólogo alemão Georg Friedrich Grotefend (1775-1853) sobre as inscrições encontradas em Persépolis que estão na origem do deciframento da escrita cuneiforme. A língua transcrita por essas inscrições era o persa antigo. Mas foi somente em 1840 que ele foi realmente decifrado por Henry C. Rawlinson (1810-1895). Será necessário esperar até 1857 para que o deciframento do acádico seja obtido a partir das traduções suficientemente consistentes, propostas por quatro cientistas - três britânicos W.H.F. Talbot (18001877), H.C. Rawlinson, E. Hincks 1792-1866) e o francês, nascido na Alemanha, J. Oppert (18251905) -, de uma inscrição real gravada sobre um prisma de argila octogonal, descoberta em 1853 por H. Rassam (1826-1910), no sítio de Assur. Foi também J. Oppert quem estabeleceu as bases do deciframento do sumério (Lion \& Michel, 2009; 2008).

Muito rapidamente, após suas primeiras explorações em meados do século XIX, a arqueologia conseguiu estabelecer que o cuneiforme foi a primeira escrita (pouco anterior àquela do Egito) da qual a humanidade fez uso. Mas no momento dessa descoberta, como acabamos de mencionar, a escrita já havia sido assunto de muitas teorizações. Praticamente todas consideravam a língua como a origem da escrita.

\footnotetext{
3 Sobre essa oposição entre uma escrita verdadeira e uma escrita "destituída", ver as análises de Derrida (1967a, p. 26-27), que mostram como ela persistiu no pensamento ocidental de Platão até o período moderno, passando pelas interpretações teológicas da Idade Média.

${ }^{4}$ N.T.: Optou-se por traduzir o trecho citado ao português a partir da tradução francesa usada no original pelo autor: PLATON. Phèdre. In : Luc Brisson [2008] (Dir.) Platon CEuvres complètes. Paris : Flammarion, p. 1241-1297.

BACHELOT, Luc. Aventuras e desventuras da escrita. A propósito da interpretação do nascimento da escrita na Mesopotâmia. Cadernos do Lepaarq, v. XVII, n.33, p. 223-250, Jan-Jun. 2020.
} 
O catálogo de uma grande exposição dedicada aos escritos cuneiformes e hieroglíficos, no Grand Palais de Paris, em 1982, especifica uma vez mais: "A escrita é a representação do pensamento e da linguagem humana por signos" (ANDRÉ-LEICKNAM \& ZIEGLER, 1982, p. 13) 5 .

Essa concepção é bastante compreensível, na medida em que os documentos sobre os quais ela se baseava, desde pelo menos o século VIII a.C., estavam inscritos em caracteres alfabéticos, dos quais uma das funções essenciais parece de fato ser a reprodução a mais exata possível do fonema. E por estarmos acostumados com isso, essa foi a abordagem usada para a análise da escrita antiga da Mesopotâmia, embora esta última não fosse alfabética ${ }^{6}$. 0 método não era nada adaptado ao seu objeto, uma vez que o uso regular dos ideogramas (signos gráficos representando objetos ou noções, e não apenas sons como as letras do alfabeto) nos textos cuneiformes mostra claramente que o escriba com certeza não tinha como preocupação principal a restituição dos fonemas.

Contudo, tendo em vista que nossa escrita alfabética era percebida como o último elo de uma longa cadeia evolutiva, aqueles que a precederam foram espontaneamente considerados esboços, necessariamente destinados a se transformar. Desde a descoberta da escrita cuneiforme não deixamos de descrever sua evolução como uma progressão lenta que nos permitiu passar de imagens (pictogramas) para sinais abstratos, cujo valor fonético final foi finalmente usado para transcrever as sílabas que compunham a cadeia do discurso falado. Definitivamente, pensou-se, era então de fato a língua que determinava a evolução morfológica dos sinais da escrita.

Essa evolução da forma, passando sucessivamente do naturalismo para um esquematismo cada vez maior até chegar ao apagamento de qualquer semelhança com um objeto qualquer do mundo, apareceu como uma teleologia, ainda que não tenha sido ignorado por ninguém que a evolução de uma forma pode ser condicionada por um contexto material ou técnico particular, variável de acordo com os lugares ou as épocas; o que não poderia ser confundido com uma predisposição natural ou essencial para qualquer evolução (DURAND, 1982, p. 57).

Veremos, então, como foi descrita essa evolução dos sinais da escrita da Mesopotâmia em direção à abstração ${ }^{7}$. Praticamente todos os manuais de epigrafia oferecem tabelas dessa evolução (Fig. $1^{8}$ ):

\footnotetext{
5 Referimo-nos a essa publicação notável pelo número considerável de documentos cuneiformes e hieroglíficos, dos mais antigos aos mais recentes, que ela apresenta e pelo conjunto das introduções, comentários e notas que os acompanham.

6 Durand (1985, p. 25-43) desenvolve precisamente todo o argumento.

7 Essa evolução foi descrita várias vezes, incluindo, entre muitas outras, as apresentações coletadas em Christin (1982, 1985, 2001), André-Leicknam \& Ziegler (1982), Talon \& Van Lerberghe (1997), assim como trabalhos de Labat (1948), Glassner (2000) e Gelb (1973).

${ }^{8}$ Reproduzimos abaixo, a título de exemplo, o que Gelb publicou em seu trabalho (1973).
} 


\begin{tabular}{|c|c|c|c|c|}
\hline \multicolumn{3}{|c|}{$\underbrace{\text { Pictogramas }}$} & \multicolumn{2}{|c|}{$\underbrace{\begin{array}{c}\text { Signos } \\
\text { cuneiformes }\end{array}}$} \\
\hline Pássaro & $\delta$ & 8 & $\vec{\nabla}$ & 辰Y \\
\hline Peixe & $\Longrightarrow$ & $\hat{\gamma}$ & $k$ & 形 \\
\hline Asno & 20 & 23 & Ant & $-\infty$ \\
\hline Boi & $\forall$ & $\Rightarrow$ & $\Rightarrow$ & 弥 \\
\hline Sol & $\infty$ & ) & $\Leftrightarrow$ & 4 \\
\hline Grão & 总 & H & . & 4 \\
\hline Pomar & 遌 & $\begin{array}{l}\text { H) } \\
\forall \gg+1\end{array}$ & 》 & 送: \\
\hline Charrua & IIIt & 自 & 示 & 虾 \\
\hline $\begin{array}{l}\text { Bumeran } \\
\text { gue }\end{array}$ & $\approx$ & $D$ & 柆 & 这 \\
\hline Pé & {[} & -1 & $x-1$ & $\leftrightarrow$ \\
\hline
\end{tabular}

Figura 1: Tabela de Evolução Morfológica de Sinais, Pictogramas (IV milênio a.C.) e Sinais Cuneiformes Tardios (I milênio a.C.). De acordo com Gelb (1973).

Todos os comentários que acompanham essas tabelas enfatizam a necessária adaptação da escrita à língua como fator determinante da evolução morfológica dos sinais. Para grafar um som, mais vale a abstração que o realismo. De fato, um sinal que se torna abstrato, tendo perdido qualquer semelhança com a realidade empírica, pode referir-se a um simples som, um fonema, de maneira convencional, sem que ninguém seja perturbado pelo significado induzido pela representação realista de um objeto qualquer. Contudo, essa evolução em direção à abstração dos sinais da escrita para uma melhor adaptação à verbalização não foi universal. Certos hieróglifos egípcios são, com efeito, ao mesmo tempo figurativos e fonéticos.

\section{Do desenho à cunha ou da pedra ao barro...}

A escrita teria então surgido, pela primeira vez na Mesopotâmia, na forma de desenhos (pictogramas) que ainda hoje podemos facilmente identificar, interpretar. Esses sinais pictográficos iniciais estavam gravados em placas de pedra que foram encontrados no sul da Mesopotâmia, sobretudo na região de Uruk. Muito rapidamente, a forma desses sinais evoluiu para se tornar mais esquemática e depois, numa fase posterior, totalmente abstrata. Por causa da forma particular em "cunha, ângulo reto" (do latim cuneus: cunha) dos elementos que compunham cada signo, essa escrita avançada foi chamada de "cuneiforme".

Essa esquematização progressiva foi, em grande parte, determinada pela natureza do 
suporte utilizado em uma segunda etapa: a argila ${ }^{9}$. Enquanto a pedra dura permite o percurso de linhas curvas, necessário para a representação de objetos, a argila fresca não é adequada para executar esses desenhos (Figura 1). A aplicação sobre a argila fresca da borda linear de um corte de estilete (calamus), levou mecanicamente à decomposição das curvas do desenho original em segmentos de linha reta ("as cunhas"). Essa rápida transformação radical da forma tornou o design original irreconhecível. Passamos, então, de imagens mais ou menos figurativas para sinais abstratos. Essa mudança na forma de escrever os sinais foi acompanhada por uma mudança de orientação dos sinais originais de $90^{\circ}$, no sentido anti-horário. Pode-se imaginar que os escribas adotaram essa nova orientação dos sinais por razões práticas, facilitando talvez, assim, a sua realização.

Depois da pictografia inicial, que nenhum elemento permite associar à uma língua em particular (um sinal mais ou menos naturalista pode ser entendido e verbalizado em línguas muito diferentes), quando os textos cuneiformes mais antigos são decifráveis, eles notam o sumério, uma língua que não pertence a nenhum dos grandes grupos linguísticos conhecidos. Mas, no sul da Mesopotâmia, apenas alguns séculos após o aparecimento dos primeiros documentos, por volta da metade do terceiro milênio a.C., o bilinguismo prevalecia. Tanto o sumério quanto o acádico (semítico antigo) eram praticados. “(...) Um texto acádico tem, na maioria dos casos, dois níveis de expressão: o ideogramático sumério e o fonético acádico, sendo os sinais, na maior parte do tempo, basicamente idênticos" (DURAND, 1977, p. 42) ${ }^{10}$.

Embora o sumério não possa ser conectado a um grupo linguístico particular, seu funcionamento e a sua estrutura lexical são agora conhecidos. Durante muito tempo, afirmou-se que se tratava de uma língua cujos itens lexicais eram principalmente monossilábicos; um objeto, ou noção, geralmente sendo designado por uma única sílaba. O caráter categórico que teve outrora a formulação dessa proposição está agora abandonado ${ }^{11}$, mas, no entanto, pode-se sustentar que esse monossilabismo, embora não exclusivo, era amplamente atestado. Contudo, era fácil combinar esse objeto com um único sinal gráfico que era chamado de "ideograma". Sendo assim, um signo representava um objeto ou uma noção, obviamente associada a um som: um fonema. Em seu princípio, o sistema é extremamente complicado, uma vez que, em teoria, ele deve mobilizar tantos sinais quanto objetos existem para designar no mundo e pensamentos para expressar. Uma vez que as possibilidades gráficas não são infinitas, vários significados, às vezes muito distantes uns dos outros, foram atribuídos ao mesmo signo. A polissemia foi assim constituída, permitindo uma economia de uma parte do repertório de sinais. Mas, além das dificuldades de interpretação que ela poderia induzir, ela não impedia a necessidade de memorização de um número considerável de sinais: não muito longe dos um milhão e meio, se considerarmos todos os sítios (arqueológicos) que

\footnotetext{
9 Toda a problemática referente à influência das condições materiais da execução da escrita (espaço disponível, natureza, dimensões do suporte, etc.), a tipologia dos textos, assim como seus conteúdos, é amplamente tratada nas contribuições reunidas nas principais obras editadas por A.-M. Christin (1982, 1985, 1995).

10 Citado por A.-M. Christin (1995, p. 53).

${ }^{11}$ Edzard (2003, p.4) evoca até mesmo um "mito monossilábico".
} 
forneceram documentos proto-cuneiformes. ${ }^{12}$

\section{Do monossilabismo sumério ao polissilabismo acádico}

No final do terceiro milênio a.C., os textos cuneiformes notam, predominantemente, o segundo idioma em uso na região, o acádico; o sumério agora era utilizado apenas como língua culta.

Sendo o acádico polissilábico (e não predominantemente monossilábico como o sumério), era necessário uma sequência de vários sinais para contemplar as diferentes sílabas que formavam uma palavra. É evidente que o significado particular que cada um deles tinha na língua suméria foi abandonado, e que apenas seu valor fonético foi levado em consideração. Para ganhar um pouco de espaço em um tablete que não oferecia muito ${ }^{13}$, o escriba às vezes optava por escrever certas palavras usando ideogramas sumérios (um sinal por palavra), no lugar dos diferentes sinais correspondentes às sílabas da palavra acádica.

Assim, com quatro sinais, o sistema monossilábico dos ideogramas sumérios podia, em teoria, notar apenas quatro noções diferentes. No sistema silábico acádico, com quatro sinais e pelo simples jogo de permutações de sílabas, era possível compor dezenas de palavras diferentes.

Muito mais tarde, no século XIV a.C., na costa síria, apareceu o alfabeto cuneiforme, que, em virtude do mesmo princípio de combinação de sinais, permitia uma economia de meio ainda maior. Agora, não eram mais as sílabas que precisavam ser encadeadas para compor as palavras, mas tão somente as letras para compor as sílabas. O número de possibilidades combinatórias de letras para formar sílabas, multiplicado pelo número de sílabas para compor uma palavra significava que, com apenas cerca de trinta sinais, era possível transcrever facilmente todos os enunciados, qualquer que fosse seu número e sua diversidade. É assim que nosso alfabeto latino ainda funciona.

\section{II- ... e suas dificuldades}

Assim, a evolução morfológica da escrita cuneiforme teria sido submetida ao imperativo da melhor adaptação possível à língua. $\mathrm{O}$ ideal seria alcançado quando a escrita aparecesse como o decalque perfeito da língua.

A narrativa dessa evolução de que a partir da representação naturalista dos objetos chega-se à produção de signos abstratos que transpõem enunciados linguísticos em um suporte visível, foi amplamente imposta ao senso comum, e regularmente alimentada por muitos estudos de especialistas. Assim, Jean Bottéro (1982, p. 13-37), seguindo Falkenstein (1936), refez os estágios dessa evolução evocando primeiro uma escrita de "coisas", que teria se tornado uma escrita de "palavras" (os ideogramas) antes de se tornar, em sua fase final, uma escrita de "letras", observando

\footnotetext{
${ }^{12}$ http://cdli.ox.ac.uk/wiki/doku.php?id=late uruk period. Veja também Nissen, 1997, p. 21-31.

${ }^{13}$ N.T.: $O$ tamanho de um tablete cuneiforme pode variar de alguns centímetros até mais de meio metro, mas a maioria tem, aproxidamente, o tamanho da palma da mão.
} 
apenas os sons emitidos pela voz (os fonemas). Um exame cuidadoso do sistema mostra, no entanto, que as categorias de "coisa" de "palavra" e "som", qualquer que seja seu valor pedagógico para uma primeira abordagem, são muito simplistas.

Para começar, vamos relembrar um fato sobre o qual normalmente insistimos muito pouco, a saber: a maioria dos sinais dos primeiros documentos escritos na Mesopotâmia não são figurativos, mas abstratos ${ }^{14}$. Para se ater simplesmente a esse aspecto concreto e quantitativo do repertório de signos, não se pode argumentar que a escrita cuneiforme nasceu da simplificação de pictogramas figurativos. As tabelas geralmente publicadas nos manuais, embora precisas, são enganosas, pois, apesar de apresentarem casos particulares, elas sugerem ser representativas de todo o sistema, o que obviamente não é o caso. Apenas a forma de algumas dezenas deles é facilmente identificável em um total de mil a mil e quinhentos, de acordo com a contagem de variantes do mesmo signo.

Além disso, Jean-Marie Durand observa que a operação da escrita só é concebível a partir do momento em que a sociedade conseguiu desenvolver um campo conceitual suficientemente estruturado e compartilhado. Além desse consenso, a mera existência de um léxico (que pode ser muito especializado e, portanto, muito pouco usado) poderia não ser suficiente.

Por outro lado, - ele precisa - devemos lembrar que todos os especialistas da pré-história notam a proliferação dos chamados signos "numinosos" (...). Assim, no momento em que apareceu, a escrita poderia, há muito tempo, fazer uso de sinais para notar algo outro que não objetos ou ações que remetem a objetos. A notação de conceito, aliás, tanto deve ter precedido a notação de "coisas", que muitas das representações primitivas, figurativas na aparência, devem ser tomadas como derivadas (simbólicas) (DURAND, 1985, p. 31).

No mesmo artigo, ele também mostra que os pictogramas, esses signos cujo naturalismo supostamente facilita a compreensão, são na verdade mais difíceis de interpretar do que os ideogramas, mais esquemáticos e surgidos mais recentemente (DURAND, 1985, p. 30).

A isso podemos acrescentar que "coisas" só existem para nós na medida em que somos capazes de percebê-las, isto é, de tomar consciência delas, de conceber uma imagem mental, na sequência de uma cadeia de operações intelectuais cuja complexidade é integralmente revelada pelas ciências neurológicas cotidianamente.

Ainda assim, na maioria das vezes, interpretar um design gráfico, seja ele qual for, é procurar pelo discurso que ele traduz. Mas, depois das numerosas pesquisas etnográficas e arqueológicas que realizou sobre práticas simbólicas, Leroi-Gourhan (1964, p. 272) chegou à conclusão de que a expressão gráfica não podia ser sistematicamente submetida àquela da língua:

\footnotetext{
${ }^{14}$ Uma simples consulta ao diretório de sinais, colocado online por Iniciativa da Biblioteca Digital Cuneiforme (CDLI), possibilita o conhecimento imediato desse fato: http://cdli.ox.ac.uk/wiki/doku.php?id=late_uruk_period.
} 
"No nível em que ainda estamos localizados, o relação da linguagem com a expressão gráfica é de coordenação e não de subordinação".

Ele também observou que, mesmo no alvorecer da humanidade, as representações do mundo exterior que floresceram nas paredes das cavernas mostravam uma autonomia radical não só em relação à língua, mas também em relação a um mimetismo primordial e sistemático da realidade. Essas obras não eram o simples decalque do real, mas resultaram de um processo de simbolização extremamente elaborado, derivado das habilidades mentais adquiridas pelo homem no decorrer de uma longa evolução. Ele acrescentou especialmente que, na arte pré-histórica, o naturalismo dificilmente foi o primeiro (estágio). Foram os ritmos que os homens pré-históricos notaram em um primeiro momento:

O que é particularmente interessante (...) é que o grafismo não começa [grifo meu] em uma espécie de expressão servil e fotográfica da realidade, mas que o vemos se organizar ao longo de dez mil anos, a partir de sinais que parecem expressar inicialmente [sublinhado por mim] ritmos, não formas (LEROI-GOURHAN, 1964, p. 265).

A morfologia dos signos cuneiformes, no entanto, evoluiu, mas, ao contrário do que é constantemente repetido, provavelmente não foi para se adaptar às formas de expressão. Um único exemplo, entre muitos outros possíveis, será suficiente para mostrar que a adaptação dos signos da escrita à língua está longe de ser generalizada nos textos cuneiformes. De fato, a partir do final do terceiro milênio a.C., o uso de um ideograma sumério, que era lido em acádico, é por certo um índice do distanciamento da escrita com relação a uma língua. A existência de um complemento fonético correspondente a uma desinência acádica ligada a um ideograma sumério, permitia pensar que a palavra podia ser lida e verbalizada como se tivesse sido inteiramente notada em acádico. Assim, a sequência dos ideogramas sumérios

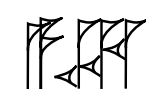

\section{A. SHÀ}

que significa "campo" era às vezes acompanhada por um dos seguintes sinais (os chamados complementos fonéticos):

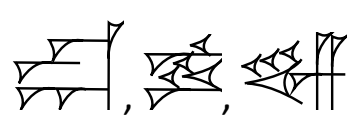

que se pronunciam respectivamente $u m$, am ou im, indicando a terminação do termo acádico que também designava o campo: eqlum, eqlam ou eqlim, dependendo do caso gramatical que se desejava distinguir. Portanto, é provável que essa sequência tenha sido lida e pronunciada eqlum, eqlam ou eqlim e não ashà um, ashà am ou ashà im.

Nesse modo de escrever não havia, neste caso, nenhuma adaptação à língua falada, mas, 
ao contrário, um distanciamento considerável e voluntário desta última, pois, por razões práticas, os sinais de outra língua eram mobilizados.

É o espaço do tablete que determina a evolução dos sinais de escrita. Jean-Marie Durand (1982, p. 51-52) descreveu precisamente esse estado de coisas para a escrita cuneiforme:

Os dois parâmetros que comandaram a evolução gráfica foram a argila, por sua qualidade mais ou menos fina e seu formato, assim como o calame, pelo calibre e tamanho que lhe foram dados. (...) É interessante examinar em que medida o material em si e seu formato podem influenciar a escrita do texto e seu significado.

Mesmo no caso de documentos legais a serem usados como prova, o texto foi escrito de acordo com o espaço disponível no tablete: "A partir de todas essas observações, deve-se concluir que a exploração utilitária de mais ou de menos espaço para escrever transforma o texto que serviria como evidência em discurso mutilado (...)" (DURAND, 1982, p. 54).

\section{III- Recurso ao contexto social e econômico}

As dificuldades de entender ou compreender o que era prórpio à escrita e, portanto, as consequências do seu aparecimento, claramente favoreceram o desenvolvimento de inúmeras análises, menos apuradas, para determinar as condições práticas e materiais do seu surgimento. Aquelas, pelo menos, haviam deixado rastros acessíveis à arqueologia. Multiplicaram-se as pesquisas sobre os contextos geográficos, econômicos, sociais, etc., das áreas onde a primeira documentação textual apareceu.

Segundo Leroi-Gourhan, foi apenas no contexto particular das sociedades que praticavam a agricultura que a escrita apareceu, isto é, entre as populações sedentárias. Depois, o fenômeno teria se generalizado no contexto das primeiras cidades.

Não há conhecimento seguro de qualquer sistema gráfico que, ainda que de longe, possa ser comparável à escrita linear em outros povos além dos agricultores (LEROI-GOURHAN, 1964, p. 275).

(...) O estabelecimento de atos de contabilidade ou genealógicos escritos é estranho ao dispositivo social primitivo, e foi somente após a consolidação dos organismos agrícolas urbanizados que a complexidade social se traduziu no aparecimento de peças autênticas tanto para os homens, como em relação aos deuses (LEROI-GOURHAN, 1964, p. 280).

A concepção de Leroi-Gourhan é encontrada em quase todos os estudos da arqueologia mesopotâmica. A referência à crescente complexidade da sociedade urbana é constante. Basta citar 
aqui alguns trechos de estudos ou manuais comumente usados:

Podemos, portanto, dizer com alguma certeza, que a organização das estruturas sociais e da economia já estavam bem estabelecidas quando começou-se a escrever; fato que destacou setores de uma economia bem desenvolvida na época (NISSEN, DAMEROW \& ENGLUND, 1993, p. 19) ${ }^{15}$.

A escrita aparece primeiro como uma maneira de registrar informações no contexto de uma complexidade crescente (...) (MATTHEWS, 1997, p. 13) ${ }^{16}$.

É fácil entender como o expansionismo econômico da cultura do Uruk tardia pode ser o contexto natural [grifo meu] da origem do primeiro desenvolvimento da escrita proto-cuneiforme (MATTHEWS, 1997, p. 14).

A necessidade de tal procedimento nasceu como um dos parâmetros dessa civilização. Baseada na agricultura intensiva de cereais e na pecuária extensiva, tudo nas mãos de um poder centralizado, ela rapidamente se enredou em uma economia tentacular, que tornou inevitável o controle meticuloso de movimentos infinitos, altamente complicados, de bens produzidos e colocados em circulação. Foi para atender a essa tarefa, para facilitar e assegurar a memorização, que a escrita foi desenvolvida; de fato, muitos séculos após sua invenção, ela quase nunca foi utilizada para algo diferente (BOTTÉRO, 1982, p. 28-31).

A urbanização e o consequente aumento da população teriam dificultado ao extremo a comunicação entre os diferentes segmentos da sociedade. Além disso, a especialização de tarefas, inerentes ao modo de vida urbano, instituiu um modo de interdependência entre os diferentes indivíduos e entre as classes sociais. O registro e o gerenciamento de trocas entre os atores econômicos teriam tornado essencial a implementação de um meio de comunicação confiável. Tal meio teria sido a escrita...

Seguindo essa lógica, poderia-se igualmente evocar outra vantagem vinculada à prática da escrita. Antes da consolidação das grandes cidades, para viver ou sobreviver era preciso negociar com elementos naturais ou parceiros em número limitado, relativamente constantes e regulares (famílias, tribos, clãs, aldeias), de todo modo, facilmente controláveis. Em um contexto urbano, o

\footnotetext{
15 "Hence, it can be adduced with some degree of confidence that the organizational structures of society and economy were already well established when literacy came into being, shedding direct light on parts of a well-developed economy of the time".

${ }^{16}$ Os comentários de Matthews, retirados de uma contribuição a um trabalho coletivo particularmente rico e informativo e aqui relatados como exemplo, são uma expressão de uma concepção amplamente compartilhada pelos vários autores do volume.
} 
modo de vida torna-se dependente de indivíduos ou grupos de indivíduos, mais ou menos distantes uns dos outros e cuja estabilidade nunca está garantida. Eles podem desaparecer, mover-se ou, por outras razões deixar de cumprir o papel ou função que em um determinado momento fora deles. A extensão do grupo social favorece naturalmente a diversidade de trajetórias e as possibilidades de mobilidade social e espacial. O bom funcionamento do grupo e a organização das operações necessárias para a sua manutenção, bem como a sua sustentabilidade, exigem que as relações sejam de alguma forma formalizadas e os objetos trocados, bens materiais ou valores ideológicos, simbolizados em formas transmissíveis e conserváveis. A escrita tinha por natureza responder de maneira eficaz e prática a essa necessidade de organização, gerenciamento e arquivamento.

Mas se a economia pôde favorecer o surgimento da escrita, podemos repetir infinitamente que isso seria somente por causa da complexidade do comércio e da organização social? A complexidade, além disso, é uma noção vaga, para a qual é difícil encontrar uma definição precisa. Quais traços deveriam caracterizar uma dada sociedade para que ela pudesse ser chamada de complexa? O número de seus componentes? Seu tamanho? O modo de dependência ou interdependência dos segmentos sociais que a constituem? A referência a um sistema de valores ou instâncias transcendentes dos quais as sociedades mais simples seriam privadas? Nada parece suficiente e necessário. A complexidade, tão difícil de definir, não pode ser um fator explicativo convincente. Podemos também reconhecer que a economia não precisava necessariamente da escrita para funcionar, mesmo em contextos urbanos e até mesmo no caso de comércio a longa distância. Sabe-se que esse se desenvolveu bem antes do período do aparecimento da escrita. Vale também lembrar que muitas pessoas completamente analfabetas, vivendo em cidades grandes e muito ativas comercial e economicamente, prescindiram e ainda prescindem da escrita ${ }^{17}$. Pode-se notar também que, se a escrita tivesse sido tão indispensável para o crescimento econômico da

\footnotetext{
${ }^{17}$ A essas observações do senso comum, vamos acrescentar as citações das obras de A. Testart, grande parte das quais constantemente submete à análise a relevância e os limites dos sistemas classificatórios das sociedades. A insistência com que esse recurso à crescente complexidade das sociedades se manifesta nas análises das ciências humanas, para explicar de maneira prosaica tudo o que é difícil de entender, justifica a nosso ver o comprimento da nota que impomos ao leitor. Em Éléments de classification des sociétés de Testart (2005, p. 19), a historiografia do uso desse conceito mostra claramente sobre quais "erros de apreciação" ele se baseia: "Em primeiro lugar, o preconceito que nos leva a considerar como 'simples e rudimentares, os povos e as culturas com costumes muito distantes dos nossos (...)' que, em contraposição, seriam necessariamente mais complexos". "Em segundo lugar, a ignorância da diferença fundamental que separa as leis da evolução técnica daquelas que presidem as transformações das sociedades (...). Pode-se (com algumas reservas, além disso) falar em crescente complexidade para a infraestrutura material de sociedades [o progresso técnico é inegável]; no que diz respeito às suas estruturas sociais, não vemos o significado que isso poderia ter". Na mesma página A. Testart lembra que "a organização da sociedade capitalista da sociedade moderna, não mais que sua organização política, não supõe (...) a organização de linhagem das sociedades africanas, nem a escravidão das sociedades antigas, nem a vassalagem da Idade Média". Portanto, não vemos de qual evolução se trata. "A ideia de crescente complexificação se baseia em terceiro lugar na metáfora biológica, na comparação abusiva entre organismo vivo e sociedade". O antropólogo dedica um apêndice inteiro à crítica dessa comparação, intitulado "Du simple et du complexe, de la métaphore biologique et des attendus implicites du terme d' "organisation"” (Do simples e do complexo, a metáfora biológica e as expectativas implícitas ao termo "organização") (TESTART, 2005, p. 135). Reconheçamos que a complexidade confrontada pelo pesquisador não é necessariamente a da sociedade que ele está estudando, mas a da própria pesquisa. Assim, evocar a complexidade do sistema socio-econômico da Mesopotâmia para explicar o nascimento da escrita se torna um topos, talvez até uma espécie de contagem etiológica.
} 
Mesopotâmia, provavelmente teriam sido encontrados infinitamente mais documentos contábeis do que o foram. Relativo à atividade econômica global da Mesopotâmia do final do quarto milênio a.C., o montante de documentos é finalmente muito limitado ${ }^{18}$.

O comércio, por outro lado, como um modo de troca, mesmo na forma de escambo, favorece as operações de simbolização. De fato, a um objeto ou propriedade é anexado um valor equivalente a outro objeto de natureza diferente. Dois objetos podem ser então trocados de acordo com um princípio da equivalência, convencionalmente adotado por cada sociedade: por exemplo, uma quantidade de grãos contra cabeças de gado, animais contra um escravo, um terreno contra uma casa, etc. E quando a troca se generaliza o sistema de equivalência também se universaliza. A simbolização assim entendida e praticada pôde ter sido um dos passos preparatórios (no nível das capacidades intelectuais dos indivíduos e grupos) para o surgimento da escrita.

O fato de uma longa cadeia de práticas específicas, técnicas e tradições ter levado à escrita foi reconhecido por um certo número de pesquisadores:

Podemos avançar a partir da ideia de que sistemas tão perfeitos quanto a escrita não são originais (...). Vista sob esse ângulo, a escrita não é nada além do que a culminação de uma longa série de tentativas de aumentar a quantidade de informação no mesmo meio (NISSEN, 1997, p. 26).

O uso de esferas de argila contendo fichas ou "tokens" (de acordo com a terminologia anglo-saxã) representando os objetos de uma transação, cuja forma e número eram impressos na superfície da esfera, tem sido frequentemente considerado como a primeira manifestação da escrita. As descobertas espetaculares feitas na acrópole de Susa, na década de 1970, representam um conjunto excepcional de dados, cujo estudo cuidadoso permitiu que os arqueológos determinasem todos as etapas percorridas entre o mero uso dessas esferas contendo fichas e o aparecimento dos primeiros sinais em uma esfera achatada: primeiro exemplo de tablete ${ }^{19}$. Se o exame desse material é perturbador, tanto quanto essa evolução parece óbvia, agora parece difícil conceber a escrita totalmente desenvolvida, tal qual ela aparece logo após o uso dessas esferas, como a simples transformação dessas marcas, uma vez que o número de sinais então utilisados ultrapassa em muito o das diferentes formas de fichas.

\footnotetext{
${ }^{18}$ Devo esse comentário a Camille Lecompte, a quem eu agradeço.

${ }^{19}$ Para o estudo dessas fichas e selos, referimo-nos à publicação desses dados primários (LE BRUN \& VALLAT, 1978), que atualmente constitui a base documental mais segura na qual se pode confiar. Objetos do mesmo tipo foram descobertos em muitos outros locais do Oriente Próximo, mas apenas as escavações de Susa forneceram um conjunto tão completo, em um contexto estratigráfico claro e perfeitamente controlado. Além disso, D. Schmandt Besserat (1998 e em particular 1992) desenvolveu amplamente a hipótese segundo a qual teríamos nessas fichas e nas marcas que elas trazem os primeiros documentos escritos.
} 


\section{IV - e o chamado para a vida após a morte...}

Para ir além dos estudos que descrevem o contexto do aparecimento da escrita, que entendemos apenas como uma etapa preparatória do processo explicativo, evoca-se por vezes a origem.

Na prática, desde que alguém naturalmente se esforçe para distinguir algo outro que não um mero começo (um lugar e um momento preciso da história), o conceito de origem abrange uma área com limites tão vastos e flutuantes (além do tempo e do espaço no domínio ilimitado das causas ou das razões diversas), que torna-se mais fácil nos perdemos a encontrar uma explicação satisfatória. Imagem do infinito que, por definição, não poderia ter começo nem fim, pois em qualquer origem é perfeitamente legítimo procurar uma origem; a origem da origem: a pergunta é inevitável, incessantemente repetida, porque para sempre sem resposta tangível. Estagnação do pensamento, talvez mais interessada do que resignada, que permite ater-se a uma evocação tão vaga quanto confortável do inexplicável, de uma dimensão metafísica imensurável, de um alhures inacessível, ao qual, no curso da história, pudemos dar os nomes de Deus, Providência, Natureza, etc. (DERRIDA, 1967, p. 90, nota 28; 1962, p. 60). A respeito da origem, apenas uma coisa precisa pode ser dita: que ela foi sucedida por uma evolução ${ }^{20}$.

Para a escrita, ao menos, sem dúvida em razão de sua generalização em todos os setores de atividades de nossas sociedades, assim como da maneira como a tornamos indispensável como meio de comunicação e preservação da informação (função antigamente assumida apenas pela tradição oral), as dificuldades teóricas geralmente relacionadas à indeterminação da origem pareciam resolvidas. A escrita apareceu como uma duplicata da língua falada, mas como um duplo mais seguro, mais eficiente e mais prático. Em suma, a origem da escrita poderia ser apenas a língua. Assim, quanto mais a escrita estivesse próxima de sua origem, daquilo a partir do quê ela fora elaborada, a língua, melhor ela seria.

Aquela que praticamos hoje parece, de fato, ser o resultado de uma longa evolução cujo objetivo era aproximá-la assintomaticamente dos enunciados linguísticos. No entanto, isso é apenas parcialmente verdadeiro, como um exame mais detalhado do que ela evidencia demonstra com facilidade. Inúmeras letras, símbolos ou caracteres escritos não são pronunciados na leitura ${ }^{21}$; e, inversamente, certos elementos fonéticos da fala pronunciada, mesmo quando carregados de significado, às vezes não correspondem a nenhum sinal gráfico. Esse é particularmente o caso de locuções como et cetera, que escrevemos com mais frequência: "etc.".

\footnotetext{
${ }^{20} \mathrm{O}$ uso desse conceito problemático sem dúvida suscitou cautela e preferência pelo conceito de nascimento, que parecia mais neutro. Mas uma nova dificuldade surgiu do uso metafórico desse termo, que indica um momento particular ou, mais precisamente, um instante, um curto instante, na longuíssima história das práticas simbólicas implementadas pela humanidade. Nunca houve um nascimento da escrita propriamente dito, ou, mais exatamente, esse nascimento foi tão longo, que não corresponde a um momento. Assim, para apoiar a hipótese do nascimento, historiadores da escrita (sejam arqueólogos, antropólogos, linguistas ou epigrafistas) mobilizam dados materiais inscritos em um contexto espaço-temporal determinado, que dificilmente pode explicar o fenômeno como um todo.

${ }^{21}$ N.T.: essas observações são em rigor válidas para a língua francesa, cuja fonética apresenta diferenças com relação àquela do português brasileiro.
} 
Mas, na evolução dos primeiros escritos, em particular na Mesopotâmia, o uso de uma grafia atestando uma preocupação de adaptação da escrita à palavra, mesmo que ocasional, foi objeto de atenção privilegiada. A escrita foi, portanto, apresentada como necessariamente segunda e secundária com relação à língua. Análises e estudos que apresentam argumentos contra essa concepção não faltam, como veremos, mas ela sempre acabou por ser restabelecida. Quaisquer que fossem os novos elementos trazidos para o dossiê, esse retorno incessante das mesmas respostas à pergunta posta, que chamamos aqui de "desventura" da escrita, revela pelo menos que, no fundo, elas deveriam parecer tão pouco convincentes, que figurava-se necessário revivê-las regularmente. Como resultado, elas sinalizavam a existência de uma pergunta não resolvida e que dificilmente seria esquecida.

A invenção da escrita foi assim apresentada como uma revolução, um milagre. Muito cedo, nas sociedades onde surgiram os primeiros documentos escritos, foram propostos os cenários do surgimento da escrita. Desde o início, sentiu-se o poder extraordinário dessa nova ferramenta de comunicação, ainda que os seus primeiros usos tenham sido extremamente limitados em comparação com aqueles que se desenvolveriam posteriormente. Sendo assim, essa invenção foi atribuída a diferentes personalidades divinas, espontaneamente, de acordo com o país. Na tradição antiga (no Oriente e no Ocidente), a invenção da escrita vincula-se à mitologia.

Na Mesopotâmia, atribuiu-se a Enmerkar, lendário rei de Uruk, a invenção da escrita, no intuito de transmitir ao soberano de Aratta (cidade distante, imaginária), seu inimigo, uma mensagem que deveria indicar sua rendição. É interessante notar que, nesse mito, é um homem e não um deus que inventa a escrita. Mas, ainda assim, deve-se resaltar que é para satisfazer a preferência da deusa do amor e da guerra, Inanna, pelo rei de Uruk, que a escrita aparece. $O$ texto diz que a mensagem do rei Enmerkar ao rei Aratta foi escrita em um pedaço de argila porque o mensageiro tinha "boca pesada".

Entende-se que é estipulado que seu "discurso é laborioso" (...) [mas] devese reter que, em nenhum caso, a invenção da escrita se destina a suprir as falhas do mensageiro incapaz de reproduzir de memória uma mensagem longa ou complexa demais para ser aprendida de cor (GLASSNER, 2000, p. 30).

O próprio símbolo do poder de Enmerkar estaria sobretudo no fato de que o destinatário da mensagem, o rei de Aratta, segurou em suas mãos aquele pedaço de argila coberto com sinais os quais ele era estritamente incapaz de decifrar, mas que contudo representava, como indicaria metaforicamente o texto gravado nele, um substituto do cetro do seu rival. Tomá-lo nas mãos significaria o reconhecimento da soberania de Enmerkar ${ }^{22}$. No entanto, não é isso o que costuma ser retido. A mensagem escrita teria sido inventada para compensar as inadequações de uma mensagem

\footnotetext{
${ }^{22}$ Glassner (2000, 38-39) oferece uma interpretação estimulante desse mito.
} 
oral, sempre sujeita a distorções ou até esquecimentos. Essa é a concepção de escrita que ainda está em voga.

Essa concepção logocêntrica deriva antes da metafísica que da observação dos fatos. Pois, o elemento original, a imagem ou a língua, é ele mesmo considerado como desprovido de história. Há, portanto, uma essencialização desse primeiro objeto, fundador, como que caído do céu. Assim, haveria uma causa que seria ela mesma sem causa. O que é um pressuposto difícil de aceitar.

A invenção da escrita (no sentido que lhe é geralmente dado, de transcrição em um suporte visível de um enunciado linguístico), como podemos ver, dificilmente pode ser atribuída a uma explicação simples e unívoca. Aceitemos a ideia de que essa invenção, como muitas outras, possa não responder a nenhuma necessidade imprescritível. Por milênios, a humanidade prescindiu da escrita, o que não a impediu de viver, de crescer, de se desenvolver e alcançar, como já apontamos, formas de organização, modos de produção ou pensamento que não são menos elaborados que aqueles que estão em uso desde a sua adoção. Além disso, vale a pena notar algo novo em nossas culturas contemporâneas: novas tecnologias que utilizam cada vez mais o reconhecimento de voz estão a uma passo de tornar a prática da escrita obsoleta, não apenas para pessoas comuns, mas também para aquelas encarregadas de produzir conhecimento e projetar dispositivos de todos os tipos, destinados a suplantar os homens em suas atividades técnicas ou mesmo criativas. ${ }^{23}$

Os estudos consagrados à escrita evocam, como vimos, as origens, o nascimento e até uma verdadeira revolução, mas sabemos que as técnicas, se é que ainda é legítimo chamar assim a escrita, não se inventam. Elas são elaborados durante uma longa gênese. É com pequenos passos, difíceis de perceber a longo do tempo que uma prática é transformada, dá forma a uma técnica que melhora ou regride. Os fatores que determinam essas constantes evoluções podem mudar ao longo do tempo.

\section{V- O pensamento da tela}

Como apontamos, há na escrita uma parte de seus signos, indispensável ao seu funcionamento, que se liberta do enunciado linguístico. Sendo assim, seria necessário prestar atenção especial à sua natureza estritamente espacial. A observação dos ideogramas (sumérios ou chineses) e dos hieróglifos egípcios permitia de imediato formular a hipótese de que a escrita, em suas realizações concretas, originava-se da imagem: "A escrita nasce da imagem e, quer o sistema a partir do qual a consideramos seja o do ideograma ou do alfabeto, sua eficácia procede somente dela mesma: essa é a tese defendida neste livro" (CHRISTIN, 1995, p. 5).

\footnotetext{
${ }^{23}$ Segundo um documentário exibido recentemente em um canal de televisão, algumas escolas nos Estados Unidos optaram por deixar de ensinar crianças pequenas a escrever manualmente, priorizando apenas iniciá-las no uso de tablets digitais. Embora esses recorram a teclados táteis e pressuponham pelo menos o conhecimento das letras e uma atividade de digitação, podemos pensar que mais ou menos a curto prazo as crianças os abandonarão em favor do controle de voz, mais rápido, mais fácil, pois não requer nenhum aprendizado, como Leroi-Gourhan já apontava em 1964: "Pode-se perguntar se a escrita já não está condenada, apesar da crescente importância dos impressos na era atual. A gravação de som, o cinema e a televisão intervieram em meio século como uma extensão da trajetória que se originou antes dos aurignacianos" (LEROI-GOURHAN, 1964, p. 294).
} 
Essa proposta, que evoca uma evidência que infelizmente e muitas vezes se perdeu de vista, conduz naturalmente à seguinte pergunta: se é a imagem que dá origem à escrita, trata-se de qualquer imagem? Ou que tipo específico de imagens é esse? Quais critérios nos permitem identificálas? Em suma, como teria se dado a passagem da imagem para a escrita? Mesmo que se deseje dar uma importância decisiva aos pictogramas, mais ou menos realistas, que aos poucos se tornam sinais cuneiformes, nada permite assimilar as imagens à escrita, pelo fato de que muitas imagens ou, mais exatamente, figuras, provavelmente a maior parte, nunca foram usadas como sinais de escrita e não têm vocação alguma para se tornar uma. O mundo das imagens não é necessariamente o mundo da escrita.

Para explicar essa passagem da imagem para a escrita, foi desenvolvido um pensamento chamado de monitor (tela), a partir do estudo dos sistemas hieroglíficos orientais. Para Anne-Marie Christin (1995, esp. p. 11-31), que defende essa concepção, depois de observar nas superfícies ou telas oferecidas pela natureza (o céu, o fígado dos animais, as carapaças de tartarugas), as marcas, os objetos e as configurações que ali se formavam, e interpretá-las como sinais emitidos por suas divindades, provavelmente os homens foram levados a conceber seu próprio sistema gráfico.

A gênese das escritas ideográficas confirma essa hipótese, pois sabemos que elas se transformaram, no caso da mesopotâmica e da chinesa, no movimento de adivinhação. A adivinhação também é uma forma de pensamento de tela: ela se baseia no exame de suportes específicos onde estão inscritos sinais da língua dos deuses, destinados a serem decifrados, pois são mensagens endereçadas por eles aos homens (CHRISTIN, 1995, p. 6) ${ }^{24}$.

George Didi-Huberman (2011, p. 30) também desenvolve essa ideia ao citar a bela

\footnotetext{
${ }^{24}$ Lembremos das palavras de J.-M. Durand (2001, p. 22-25), nas quais A.-M. Christin se baseia: "As condições do aparecimento da escrita devem ter sido concretizadas quando foram constituídos os campos nocionais que se impuseram suficientemente à consciência dos usuários de modo que pudessem ser notados, feito que, exceto a análise fonética da língua, remonta à época em que surgiram os proto-sistemas em ordem alfabética. O nocional (observado) vem primeiro na escrita, não o fonético (dito). Essa abordagem não conceitual e não fonética das realizações básicas da escrita suméria pode ser vista na notação de nomes de lugares ou divindades. O sumério podia notar a fonética pura... [mas] não o fez no caso dos nomes dos lugares porque, para os últimos, o valor conceitual deles era mais forte. Como é o caso da cidade santa de / Nippur / notada por sua principal divindade ENLIL, que se une à noção de LUGAR. A cidade é, portanto, INLIL-LUGAR. A conceituação é anterior ao momento em que o código sumério linear foi corrigido. (...) O surgimento da escrita foi condicionado à elaboração de noções fundamentais, possibilitando a análise e a expressão do mundo. (...) Por conseguinte, é necessário introduzir (...) a noção de "texto" e "leitura" (...) aqueles que o escreveram queriam valorizar a comemoração e não a comunicação (...). Essa noção de texto complexo foi imposta porque, pelo menos na Mesopotâmia, é necessário considerar a atividade de leitura como aquela que deve ter sido primeiramente praticada (...) entre esses textos arbitrariamente constituídos, dois gêneros devem ter tido originalmente uma importância considerável, embora os conheçamos apenas por suas formas recentes: aquela que consiste em ler a vontade dos deuses a partir de corpos celestes e aquela que o permite a partir da superfície do fígado. Pode-se supor agora que a escrita na Mesopotâmia apareceu, não para as necessidades utilitárias da contabilidade... mas como a consequência de uma conduta religiosa, talvez a serviço do Estado que estava se constituindo ou para prever os grandes deslocamentos dos comerciantes sumérios de Uruk".
} 
expressão de J. Nougayrol (1968, p. 32), "Ler o que jamais foi escrito".

Para Anne-Marie Christin, de qualquer forma, escrever é uma questão de imagem, manipulação do espaço. A escrita viria da imagem e não da palavra.

Mas, no entanto, se houvesse precisamente apenas escrita do espaçamento e do mais material, do mais visível? Se acaso a experiência fenomenológica do vazio tivesse sido mais determinante na invenção do ideograma do que aquela da figura ou do signo? Essa é a questão-chave que deve ser posta por qualquer teoria da escrita que coloque a origem do sistema na comunicação gráfica. Essa de fato não se permite analogias linguísticas que seriam mais ou menos localizáveis na escrita, como a linearidade ou a divisão fonética dos signos, mas uma descrição elementar da imagem, que pode ser resumida em poucas palavras: se é verdade que a imagem pertence à categoria de espaço, é preciso primeiro admitir que sua superfície é primordial, ou seja, anterior às figuras apresentadas, de forma que essas figuras the sejam tributárias, assim como os intervalos que as separam devem preservar seu valor (CHRISTIN, 1995, p. 17).

O grande mérito do pensamento da tela/monitor é ter enfatizado como a escrita deveria ter sido analisada primeiramente, de acordo com o que ela é concretamente, com a sua materialidade, ou seja, em função de um tratamento do espaço. Na gênese da escrita, como vimos, a língua sempre foi considerada como o elemento fundamental. Ter insistido no tocante ao que ela devia à imagem, tornava-se então essencial.

Mas pode-se ter percepção de uma superfície vazia de signo? O sinal não é o que faz a tela aparecer?

Além disso, pode-se imaginar que os homens tenham reconhecido no movimento das estrelas, na configuração das escamas da tartaruga ou no aspecto do fígado dos animais sacrificados a escrita dos deuses, se eles já não tivessem uma concepção de escrita?

Não podemos pensar que foi na medida em que eles já praticavam a escrita que eles viram nos fenômenos observados uma escrita que os deuses pretensamente lhes haviam destinado?

Os trabalhos recentes da neurobiologia mostram, em todo caso, que a percepção do espaço está muito longe de ser espontânea:

"Vemos porque agimos e podemos agir precisamente porque vemos", escreveu George Herbert Mead cerca de um século atrás, apontando que a percepção seria incompreensível "sem o controle contínuo da visão pela mão, e reciprocamente" (MEAD, 1938, p. 388 apud RIZZOLATTI \& SINIGAGLIA, 2008, p. 59). 
A percepção seria inteiramente determinada por nossas possibilidades de ação. Se evocarmos uma gênese da humanidade em que os homens, à partir da observação das estrelas no céu, por exemplo, seriam levados a inscrever seus próprios sinais em uma superfície que eles mesmos teriam confeccionado, podemos nos apoiar nas experiências de psicogênese que possibilitam compreender o papel capital da ação na própria consciência do espaço.

De acordo com ele [Poincaré], de fato, é preciso não apenas rejeitar “a ideia de umo suposto senso de espaço que nos faria localizar nossas sensações dentro de um espaço definido", mas convém reconhecer que não poderíamos "ter construído o espaço se não tivéssemos um instrumento para medi-lo". Ora, "este instrumento ao qual reportamos tudo, do qual nos servimos instintivamente, é o nosso próprio corpo. De fato, é em relação ao nosso corpo que situamos os objetos externos, e as únicas relações espaciais desses objetos que podemos representar para nós mesmos são as relações com o nosso corpo (POINCARÉ, 1989, p. 55 apud RIZZOLATTI \& SINIGAGLIA, 2008, p. 78).

De acordo com as análises anteriores, e graças às intuições de Mach e Poincaré, sabemos que o espaço toma forma a partir dos objetos e da multiplicidade dos atos coordenados que nos permitem alcançá-los. E como os próprios objetos são apenas hipóteses de ação, os lugares do espaço não são definidos como "posições objetivas" em relação a uma posição também supostamente objetiva de nosso corpo, mas como nos ensina Merleau-Ponty, eles "registram em torno de nós o escopo variável de nossos objetivos ou gestos" (MERLEAU-PONTY, 1945, p. 164 apud RIZZOLATTI E SINIGAGLIA, 2008 p. 88).

Aqui é difícil não evocar as propostas de Leroi-Gourhan, que no entanto não são mencionadas por Rizzolatti e Sinigaglia.

As primeiras testemunhas de um grafismo colocam-se diante de um fato muito importante. Vimos (...) que a tecnicidade bipolar de muitos vertebrados levou os antropianos à formação de duas duplas funcionais (mão-ferramenta e face-língua), envolvendo principalmente a motricidade da mão e da face na modelagem do pensamento em instrumentos de ação material e em símbolos sonoros. O surgimento do símbolo gráfico, no final do reino dos paleantropos, pressupõe o estabelecimento de novas relações entre os dois pólos operatórios, relações que são exclusivamente características da humanidade no sentido estrito do termo, ou seja, respondendo a um pensamento simbolizante. Nesses novos relacionamentos, a visão ocupa o 
lugar predominante nas duplas de face-leitura e de mão-escrita (...) (LEROIGOURHAN, 1964, p. 262).

\section{VI- A "arquiescrita" de Derrida}

Por que, então, optou-se tão obstinadamente por se pensar a escrita como uma mera substituta da fala? Obviamente, em nossas sociedades ocidentais, a prática regular, ao longo de mais de dois milênios, de um sistema alfabético mais próximo da tradução fonética do que qualquer outro, nos fez perder de vista o fato de que outras interpretações eram possíveis, mesmo entre aqueles cujo objeto de estudo eram escritas não alfabéticas. Mas, já há meio século, Derrida (1967a) denunciava os pressupostos poderosos que sustentavam o cenário sempre retomado da língua como origem da escrita. Sua "desconstrução" apontava, assim, questões ideológicas, por intermédio das quais a tradição filosófica ocidental - dando uma preferência acentuada e regularmente lembrada a uma interpretação que se tornara a vulgata da invenção da escrita - deve ter garantido sua preeminência e até seu domínio sobre as outras culturas. Derrida (1967a, p. 17) considera que:

O privilégio da phoné não depende de uma escolha que poderia ter sido evitada. Ele responde a um momento da economia (digamos, da "vida", da "história" ou "do ser como relação consigo mesmo"). O sistema do "ouvir falar" através da substância fônica - que se apresenta como um significante não externo, não-mundano, portanto não-empírico ou não-contingente deve ter dominado durante toda uma época do mundo, até mesmo produzido a ideia do mundo, a ideia da origem do mundo a partir da diferença entre o mundano e o não-mundano, o exterior e o interior, a idealidade e a nãoidealidade, o universal e o não-universal, o transcendental e o empírico, etc.

Assim, desde Platão, a escrita apareceu como um derivado da língua, substância na qual o pensamento se manifesta pela primeira vez.

A voz é ouvida - é provavelmente o que chamamos de consciência - o mais próximo possível de si como a obliteração absoluta do significante: pura autoafeição, que necessariamente tem a forma do tempo e que não imprime fora de si mesmo, no mundo ou na "realidade", nenhum significante acessório, nenhuma substância de expressão estranha à sua própria espontaneidade. É a expressão única do significado que ocorre espontaneamente, de dentro de si e, no entanto, enquanto um conceito significado, no elemento da idealidade ou da universalidade (DERRIDA, 1967a, p. 33).

Retornando à sua última conclusão, o comentário de Derrida era explosivo: “... a 
pretensa derivação da escrita, por mais real e maciça que ela seja, só foi possível sob uma condição: que a língua 'original', 'natural', etc. jamais tenho existido, que ela nunca tenha se mantido intacta, intocada pela escrita, que ela mesma sempre tenha sido uma escrita." (DERRIDA, 1967a, p. 82) ). $^{25}$

Essa afirmação assumiu a forma de uma virada total do modelo explicativo que gerações de pensadores nunca tinham deixado de consolidar, uma vez que argumentava que era a escrita que estava na origem da língua e não o inverso. A resistência - que, pode-se supor, testemunha um temor - a esse questionamento radical e espetacular, assumiu a forma de um silêncio obstinado. De fato, a quase totalidade dos estudos sobre o surgimento ou a história da escrita, atribuível aos diferentes especialistas das áreas culturais onde são atestadas o que se considera como sendo as primeiras evidências da escrita, ainda que numerosos após a publicação dos trabalhos de Derrida, não levou em consideração ou, mais grave talvez, nunca tenha chegado a conhecer as suas propostas ${ }^{26}$.

Para explicar tal situação, pode-se, sem dúvida, mencionar a compartimentação disciplinar que caracteriza o mundo da pesquisa. A isso, deve-se acrescentar que, a dificuldade de leitura dos textos de Derrida dificilmente incentivava a abordagem de um pensamento que, além disso, diziase frustrar o que sempre se havia pensado e parecia fundamentar-se em evidências difícilmente contestáveis. No entanto, basta lê-lo, Derrida nunca cedeu à simples facilidade ou ao prazer do gesto iconoclasta que varre ideias, teorias ou atitudes, tão pesadas quanto paralisantes por terem durado demais. Sua estratégia não era fazer tábua rasa do passado, mas desmontar pacientemente todas as engrenagens, todas as estratégias, jogos e truques que os sistemas de pensamento criaram para se opor à extrema complexidade da realidade, uma visão sustentada por um determinismo simples, tranquilizador e que promete um certo (mas muito problemático) controle sobre os fatos, bem como um certo controle sobre aqueles que acreditam nele. Tanta atenção à fluidez dos fenômenos estudados e à sutileza dos mecanismos usados para analisá-los também chegou a proposições não menos surpreendentemente densas, claras e estritamente delimitadas como aquela que, contra qualquer expectativa, fazia da escrita o modelo da língua. A nova linha de pensamento ultrapassa largamente os limites do campo particular da escrita e de sua história, para atravessar todas as áreas do pensamento ocidental rumo a horizontes até então inimagináveis. A reformulação da questão da escrita feita por Derrida trouxe consigo [a crítica] integral ao pensamento ocidental: “O problema da escrita e do domínio de seu potencial coloca em jogo a distinção entre filosofia e sofística, distinção sem a qual a filosofia não poderia se diferenciar nem se instituir" (GOLDSCHMIT, 2003, p. 32) 27.

\footnotetext{
${ }^{25}$ Todo o livro de Derrida (Gramatologia) é dedicado a esse questionamento.

${ }^{26}$ Seria sem dúvida necessário o olhar de um observador externo ao campo disciplinar dentro do qual a necessidade do processamento imediato dos dados empíricos dificilmente permite o distanciamento indispensável ao progresso teórico, para desenvolver seu trabalho e avançar uma nova tese. Foi o trabalho de Anne-Marie Christin que diversas vezes reuniu os especialistas das diferentes escritas e defendeu a tese do pensamento da tela.

${ }^{27}$ Além da leitura indispensável das obras de Derrida (De la grammatologie, 1967a; La voix et le phénomène, 1967b; sua introdução a L'origine de la geómétrie, de Husserl, 1962, deve-se ler ainda ao mesmo tempo o trabalho muito sintético e esclarecedor de Marc Goldschmit (2003). Em português: DERRIDA, J. Gramatologia. São Paulo: Perspectiva, 2011; DERRIDA, J. A voz e o fenômeno. 1a ed. Rio de Janeiro: Zahar, 1994. Já a introdução de Derrida à tradução francesa da Origem da geometria de Husserl encontra-se parcialmente traduzida em: RODRIGUES, Carla. Excerto de Introdução à Origem da Geometria. Revista em construção (Rio de Janeiro), 3, p. 63-73, 2018. Goldschmit 2003 não conta com tra- 


\section{A arquiescrita}

A escrita não poderia ser um substituto da língua. Se fosse, só poderia sê-lo de uma língua original que em seu funcionamento deve pouco à língua falada da qual, no entanto, não cessamos de repetir que ela deriva.

Além disso, a língua nunca poderia ter nascido e se desenvolvido sem a existência prévia de uma escrita, no estágio de modelo ou de sistema teórico que poderia muito bem estar em funcionamento, sem ter conhecido uma realização concreta, isto é, a produção de texto legível em um suporte. Essa escrita teórica, esse modelo, Derrida chamou de "arquiescrita", justamente para distingui-la da escrita no sentido comum do termo. Se ousássemos uma fórmula paradoxal, diríamos que a escrita existia antes mesmo de ser visível e que, apesar das evidências, neste caso enganosas, da história, a escrita não foi um subproduto, uma continuação, um suplemento da língua, mas sim a sua condição de possibilidade. A escrita teria, in abstracto, precedido e não sucedido à língua.

Para determinar no que a escrita ou a arquiescrita é uma condição para o desenvolvimento e o funcionamento da língua, convém recordar muito brevemente a definição da língua, tal qual a linguística estrutural estabeleceu.

A língua é definida como um sistema de signos (SAUSSURE, 1915), entidades com duas faces, uma das quais é o significado, ou seja, a significação; a outra, o significante, a palavra, também chamada "imagem acústica". O que liga esse signo linguístico à realidade (ao ou aos "referentes") a qual ele serve para designar é "arbitrário", isto é, estritamente convencional. Não há nenhuma ligação natural (de semelhança, identidade funcional ou outra) entre o signo linguístico e os objetos do mundo. A palavra "mesa" não tem nada a ver com o objeto mesa, a palavra "sol" com o astro, etc. A essa definição que parece ter se imposto de forma definitiva desde o trabalho de Saussure, Derrida (1967a, p. 65) acrescenta:

Se "escrita" significa inscrição e inicialmente instituição duradoura de um signo (e esse é o único núcleo irredutível do conceito de escrita), a escrita em geral abrange todo o campo dos signos linguísticos (...). A própria ideia da instituição - de arbitrariedade do signo - é impensável antes da possibilidade da escrita e fora de seu horizonte.

De fato, a permanência de uma forma, sua duração no tempo dificilmente seria identificável sem a marca ou a inscrição na matéria.

Por outro lado, sabemos desde Saussure, que o significado dos enunciados, assim como aquele dos termos que o compõem, é elaborado apenas pelo jogo das oposições que podem ser estabelecidas entre eles: "Se as palavras e os conceitos só fazem sentido em uma série de diferenças - continua Derrida - só podemos justificar sua linguagem e a escolha dos termos no interior de um tópico e de uma estratégia histórica" (DERRIDA, 1967a, p. 102).

É então que o filósofo traz a noção de traço. Ela refere-se especificamente àquilo que não está lá. Se é difícil admitir a existência de um significante que esteve sempre presente, permanente 
e universal, uma vez que é o jogo de oposições que faz sentido, a arbitrariedade daquilo que liga o significante ao significado só pode designar o apagamento de um significado transcendente. $O$ valor semântico e sua manifestação material (gráfica ou fônica) nunca são nada além de traços: “... essa noção [de traço] significa ... o abalo de uma ontologia que, em seu curso mais profundo, determinou o sentido do ser como presença e o sentido da linguagem como uma continuidade total da fala" (DERRIDA, 1967a, p. 103).

É exatamente por isso que a língua não é esse objeto puro onde se manifestam o conceito, o pensamento, o ser, a essência etc., que um dia poderia ser tomado por um meio mais prático: a escrita. Não! A língua, a palavra é sempre em si, uma escrita: “(...) qualquer marca - diz Derrida - mesmo que seja oral, é um grafema (...)" (DERRIDA, 1972, p. 378).

\section{CONCLUSÃO}

Que a escrita, no sentido comum da palavra, foi, na época de suas primeiras realizações, uma forma de imagem, é difícil refutar! Que ela foi engendrada pela leitura, como apontado por Anne-Marie Christin? Sem dúvida! Lembrar que os homens puderam ver no espaço, marcado por múltiplos fenômenos, uma forma de escrita, era essencial para ir além das interpretações tradicionais, fundamentadas em uma concepção estritamente linguística.

Deveríamos então reconduzir a relação entre escrita e língua a uma visão mais justa: a escrita e a fala são uma manifestação da atividade simbólica, sem que a primeira seja necessariamente sujeita à segunda. A relação de uma para com a outra não é vertical ou descendente, mas horizontal.

A escrita aparece assim, como vimos, quando um campo nocional é suficientemente elaborado para ser expresso por outros meios que não o da língua. Até recentemente, o reconhecimento de tais fenômenos, ainda que respaldado por uma longa experiência da observação e da pesquisa, era hipotético. A partir de agora, os trabalhos realizados pela neurobiologia (RIZZOLATTI \& SINIGAGLIA, 2008) fornecem a base experimental que lhe faltava: a demonstração do substrato biológico constituída pelo mecanismo dos neurônios-espelho na transmissão de knowhow, assim como na constituição de um campo nocional compartilhado. Esses avanços científicos são fascinantes, mas nunca, é claro, revelam qualquer determinismo biológico absoluto. $O$ que passa de geração em geração, que se sedimenta, que se fortalece ou desaparece, para reaparecer eventualmente mais tarde e levar ao que chamamos de invenções, é uma questão de escolha, de circunstâncias, nas quais a mistura da consciência ou do inconsciente opera, e a pesquisa deve desconstruir.

Hoje, é indubitavelmente necessário empreender uma reflexão em que uma descoberta "positiva" e a "desconstrução" da história da metafísica, em todos os seus conceitos, controlem-se mutuamente, minuciosamente, meticulosamente (DERRIDA, 1972, p. 124). 


\section{REFERÊNCIAS BIBLIOGRÁFICAS}

AMIET, P. Introduction historique. IN: ANDRÉ-LEICKMAN, B. \& ZIEGLER, Chr. (orgs.). Naissance de l'écriture. Cunéiformes et hiéroglyphes. Catalogue de l'exposition aux Galeries nationales du Grand Palais, 7 mai-9 août 1982. Paris: Édition de la Réunion des Musées Nationaux, 1982, p. 17-27.

ANDRÉ-LEICKMAN, B. \& ZIEGLER, Chr. (orgs.). Naissance de l'écriture. Cunéiformes et hiéroglyphes. Catalogue de l'exposition aux Galeries nationales du Grand Palais, 7 mai-9 août 1982. Paris: Édition de la Réunion des Musées Nationaux, 1982.

BOTTÉRO, J. Écriture et civilisation en Mésopotamie. IN: ANDRÉ-LEICKMAN, B. \& ZIEGLER, Chr. (orgs.). Naissance de l'écriture. Cunéiformes et hiéroglyphes. Catalogue de l'exposition aux Galeries nationales du Grand Palais, 7 mai-9 août 1982. Paris: Édition de la Réunion des Musées Nationaux, 1982, p. 28-31.

BOTTÉRO, J. De l'aide-mémoire à l'écriture. IN: CHRISTIN, A.-M. (org.). Écritures: systèmes idéographiques et pratiques expressives. Paris: Le Sycomore, 1982b, p. 13-37.

CHRISTIN, A.-M. (org.). Écritures: systèmes idéographiques et pratiques expressives. Paris: Le Sycomore, 1982.

CHRISTIN, A.-M. (org.). Écriture II. Paris: Le Sycomore, 1985.

CHRISTIN, A.-M. L'image écrite ou la déraison graphique. Paris: Flammarion, 1995.

CHRISTIN, A.-M. (org.). Histoire de l'écriture. De l'idéogramme aux multimédia. Paris: Flammarion, 2001.

DERRIDA, J. Introduction. IN: HUSSERL, E. L'origine de la géométrie. Paris: PUF, 1962.

DERRIDA, J. De la grammatologie. Paris: Minuit, 1967a.

DERRIDA, J. La voix et le phénomène. Introduction au problème du signe dans la phénoménologie de Husserl. Paris: PUF, 1967b.

DERRIDA, J. Marges de la philosophie. Paris: Les Edition de Minuit, 1972.

DESTUTT DE TRACY, A. Éléments d'idéologie. Seconde partie. Grammaire. Paris: Courcier libraireéditeur, 1803.

DIDI-HUBERMAN, G. Atlas ou le Gai savoir inquiet - L'œil de I'histoire, 3. Paris: Les Editions de Minuit, 2011.

DURAND, J.-M. Diffusion et pratiques des écritures cunéiformes au Proche-Orient ancien. L'espace et la lettre, Cahier de Jussieu, 3, 10/18, p. 13-59, 1977.

DURAND, J.-M. Espace et écriture en cunéiforme. IN: CHRISTIN A.-M. (org.). Écritures: systèmes 
idéographiques et pratiques expressives. Paris: Le Sycomore, 1982, p. 51-64.

DURAND, J.-M. Trois approches de la notion d'idéogramme sumérien. IN: CHRISTIN, A.-M. (org.). Écriture II. Paris: Le Sycomore, 1985, p. 25-43.

DURAND, J.-M. L'écriture cunéiforme. IN: CHRISTIN, A.-M. (org.). Histoire de l'écriture. De I'idéogramme aux multimédia. Paris: Flammarion, 2001, p. 22-25.

EDZARD, D. O. Sumerian Grammar. Leiden, Boston: Brill, 2003.

FALKENSTEIN A. Archaische Texte aus Uruk. Berlim: Deutsche Forschungsgemeinschaft, 1936.

GELB, I.-J. Pour une théorie de l'écriture. Paris: Flammarion, 1973 (1952).

GLASSNER, J.-J. Écrire à Sumer, l'invention du cunéiforme. Paris: Seuil, 2000.

GOLDSCHMIT, M. Jacques Derrida, une introduction. Paris: Pocket, la Découverte, 2003.

LABAT, R. Manuel d'épigraphie akkadienne. Paris: Librairie Orientaliste Paul Geuthner, 1948.

LE BRUN, A. La glyptique du niveau 17B de l'Acropole (campagne 1972). Cahiers de la Délégation Archéologique Française en Iran, ${ }^{\circ} 8, \mathrm{p} .61-80,1978$.

LE BRUN, A. \& VALLAT, F. L'origine de l'écriture à Suse. Cahiers de la Délégation Archéologique Française en Iran, n8, p.11-60, 1978.

LEROI-GOURHAN, A. Le geste et la parole, technique et langage. T1. Paris: Albin Michel, 1964.

LION, B. \& MICHEL, C. (orgs.). Les écritures cunéiformes et leur déchiffrement. Paris: De Boccard, 2008.

LION B. \& MICHEL C. (orgs.). Histoires de déchiffrements. Les écritures du Proche-Orient à l'Égée. Paris: Éditions Errance, 2009.

MATTHEWS, R. L'émergence de l'écriture au Proche-Orient. IN: TALON, Ph. \& VAN LERBERGHE, K. (orgs.). En Syrie, aux origines de l'écriture. Turnhout: Brepols, 1997, p. 13-19.

MEAD, G. H. The Philosophy of the act. Chicago: Chicago University Press, 1938.

MERLEAU-PONTY, M. Le Visible et l'invisible. Paris: Gallimard (Tel), 1964a.

MERLEAU-PONTY, M. L'œil et l'esprit. Paris: Gallimard, 1964b.

MERLEAU-PONTY, M. La phénoménologie de la perception. Paris: Gallimard, 1945.

NISSEN, H. L'invention de l'écriture cunéiforme, les tablettes archaïques d'Uruk. IN: TALON, Ph. \& VAN LERBERGHE, K. (orgs.). En Syrie, aux origines de l'écriture. Turnhout: Brepols, 1997, p. 21-31.

NISSEN, H.; DAMEROW, P. \& ENGLUND, R. Archaic Bookkeeping, Early Writing and Techniques of Economic Administration in the Ancient Near East. Chicago and London: The University of Chicago Press, 1933. 
NOUGAYROL, J. La divination babylonienne. IN: CACQUOT, A. \& LEIBOVICI, M. (orgs.). La Divination. Paris: PUF, 1968, p. 25-81.

PETIT, J.-L. Constitution by movement: Husserl in light of recent neurobiological findings. IN: PETITOT, J.; VARELA, F. J. \& PACHOUD B.; ROY J.-M. (orgs.). Naturalizing Phenomenology: Issues in Contemporary Phenomenology and Cognitive Sciences. Stanford: Stanford University Press, 1999, p. 220-244.

PETITOT, J.; VARELA, F. J.; PACHOUD B. \& ROY J.-M. (orgs.). Naturalizing Phenomenology: Issues in Contemporary Phenomenology and Cognitive Sciences. Stanford: Stanford University Press, 1999. (Traduit en français: Naturaliser la phénoménologie. Essais sur la phénoménologie contemporaine et les sciences cognitives, Paris: CNRS Editions, 2002).

PLATON. Phèdre. IN: BRISSON, Luc (dir.). Platon CEuvres complètes. Paris: Flammarion, 2008, p. 1241-1297.

POINCARÉ, H. La Science et l'Hypothèse. Paris: Flammarion, 1989 (1908).

RIZZOLATTI, G. et al. Premotor cortex and the recognition of motor actions. Cognitive Brain Research, 3, p. 131-141, 1996.

RIZZOLATTI, G. \& SINIGAGLIA, C. Les neurones miroirs. Paris: Odile Jacob (Poches), 2008 (2006).

SAUSSURE, F. Cours de linguistique générale. Paris: Payot, 1976 (1915).

SCHMANDT-BESSERAT, D. Token at Uruk. Baghdader Mitteilugen, 19, p. 1-175 e 471, 1988.

SCHMANDT-BESSERAT, D. Before Writing. From counting to cuneiform. vol. 1 Austin: University of Texas Press, 1992.

TALON, Ph. \& VAN LERBERGHE, K. (orgs.). En Syrie, aux origines de l'écriture. Turnhout: Brepols, 1997.

TESTART, A. Éléments de classification des sociétés. Paris: Errance, 2005. 